\title{
Effect of therapeutic plasma exchange on plasma levels and total removal of adipokines and inflammatory markers
}

\author{
Julius J. Schmidt ${ }^{1 \dagger}$, Janine Jahnn ${ }^{2 \dagger}$, Paulina Golla ${ }^{1}$, Carsten Hafer ${ }^{1}$, Jan T. Kielstein ${ }^{1 * \dagger}$ and Heike Kielstein ${ }^{2 \dagger}$
}

\begin{abstract}
Background: Aside from well-established inflammatory mediators adipokines have recently been found to play an important role in a variety of immunologic diseases. Therapeutic plasma exchange (TPE) is an established treatment modality for the acute removal of pathophysiological relevant disease mediators. The aim of this study was to determine adipokine removal during TPE therapy.

Methods: 21 Caucasian patients (10 females, 11 males) with an indication for TPE using albumin as exchange fluid received two consecutive TPE sessions. Blood samples for measurement of resistin, leptin, sICAM-1, sCD40L, MCP-1, and sTNF-R were drawn before and at the end of each TPE session. Samples from the total removed plasma were collected at the end of every treatment.

Results: We found a significant reduction in pre- vs. post-TPE plasma concentrations for sICAM-1 (517 \pm 246 vs. 260 $\pm 159 \mathrm{ng} / \mathrm{ml}, p<0.0001)$, sTNF-R ( $8.1 \pm 6.4$ vs. $5.7 \pm 3.9 \mathrm{ng} / \mathrm{ml}, p<0.05)$, and resistin plasma levels (14.3 \pm 6.9 vs. $9.5 \pm$ $4.7 \mathrm{ng} / \mathrm{ml}, p<0.001$ ). Solely sICAM-1 reduction persisted for $25 \pm 5 \mathrm{~h}$ between the first and second TPE treatment, while the other investigated mediators increased to baseline levels. Substantial amounts of all measured mediators could be recovered from the removed plasma.

Conclusions: TPE provides a persistent reduction in SICAM-1 levels and temporarily affects several adipokine and cytokine plasma levels. Our findings are of importance not only for the interpretation of blood levels of cytokines in patients undergoing TPE but provide solid evidence that TPE markedly decreases sICAM-1.
\end{abstract}

\section{Background}

Therapeutic plasma exchange (TPE) is an extracorporeal treatment modality separating and removing blood plasma and replacing it with a protein containing fluid such as albumin [1]. It is performed in an increasing number of mainly immunologic disorders to remove substances with a high molecular weight such as antibodies, antibodyantigen complexes, and paraproteins [2]. In addition, due to the unselective removal of plasma, other plasma components like inflammatory mediators get eliminated as well. This may play a role in inflammatory states, as for example sepsis with multi-organ failure, where TPE has

\footnotetext{
* Correspondence: Kielstein@yahoo.com

Julius J. Schmidt and Janine Jahn are co first authors. Jan T. Kielstein and Heike Kielstein are co senior authors.

${ }^{\dagger}$ Equal contributors

'Department of Internal Medicine, Division of Nephrology and Hypertension, Medical School Hannover, Carl-Neuberg-Strasse 1, 30625 Hannover, Germany Full list of author information is available at the end of the article
}

been employed [3-5]. So far, data regarding the removal of inflammatory mediators during TPE are scarce. This is especially true for adipokines, which have lately been found to mediate inflammatory processes. The adipose tissue, the origin of these substances, is described as the body's largest endocrine active organ, which contributes to a chronic low-grade inflammatory state in obese patients [6]. In this regard, the adipokine leptin is known to influence mammals' food intake and energy balance as well as inflammatory processes after stimulated by cytokines or lipopolysaccharides [7-9]. Intercellular Adhesion Molecule 1 (ICAM-1) orchestrates the migration of inflammatory cells [10]. sICAM-1, the soluble form of ICAM-1, has been shown to be elevated and of pathophysiological importance in immunologic disorders as vasculitis [11], a condition for which TPE is used on a regular basis [12]. Besides their key role in regulating inflammatory processes, adipokines and cytokines are also 
biomarkers in numerous disorders, where their plasma level is related to the disease activity like in systemic lupus erythematodes $[13,14]$. In general, sICAM-1 is viewed as a biomarker for endothelial activation [15].

The aim of this study was to investigate the effect of TPE on inflammatory markers / adipokines, to quantify their removal, and to assess their rebound after the treatment.

\section{Methods}

The study was approved by the local Ethics Committee of Hannover Medical School, Germany protocol \# 5343. All patients gave written informed consent before enrolment into the study. We started the study with 21 Caucasian patients (10 females and 11 males with a mean age of $51.6 \pm 13.5$ years and a BMI of $25.1 \pm$ $5.0 \mathrm{~kg} / \mathrm{m}^{2}$ ) with indication for TPE due to various diseases including humoral rejection after solid organ transplantation, Guillain-Barré syndrome, monoclonal gammopathy, multiple sclerosis, rapid progressive glomerulonephritis, polyneuritis, microscopic polyangitis, and cryoglobulinemia. Further patients' characteristics and details of the procedure are described elsewhere [16].

Every patient received two consecutive TPE sessions during the study. Plasma exchange therapy was performed using either the Spectra Optia ${ }^{\circ}$ (TerumoBCT Inc., USA) or the Octo Nova (DIAMED Medizintechnik GmbH, Germany) apheresis system. Anticoagulation was applied either by heparin or citrate. The prescribed dose of exchange volume of every TPE treatment was 1.1-times the individual calculated total plasma volume, using the Nadler-Allen equation.

A substitute fluid with $5 \%$ albumin concentration was used in every treatment. Blood samples for measurement of different adipokines / obesity markers as resistin $(12.5 \mathrm{kDa})$, leptin $(16 \mathrm{kDa})$, sICAM-1 $(80-110 \mathrm{kDa})$, soluble CD40 ligand (sCD40L, $39 \mathrm{kDa})$, monocyte chemoattractant protein-1 (MCP-1, $13 \mathrm{kDa})$, soluble tumor necrosis factor receptor (sTNF-R, $60 \mathrm{kDa})$, and routine chemistry were drawn before (pre-TPE) and at the end (post-TPE) of the first and second TPE session. Samples at the end of each TPE treatment were collected before the rinse back of the blood. Additionally, plasma samples from the waste bags were drawn after each treatment. Blood samples were immediately cooled on ice, centrifuged at $1500 \mathrm{~g}$, and $4{ }^{\circ} \mathrm{C}$ for $10 \mathrm{~min}$. Plasma samples were stored in $1 \mathrm{ml}$ aliquots at $-80^{\circ} \mathrm{C}$ until further use.

\section{Analysis of plasma adipokines and cytokines}

Leptin, resistin, soluble CD40 ligand (sCD40L), sICAM1 , soluble tumor necrosis factor receptor (sTNF-R), and monocyte chemoattractant protein 1 (MCP-1) were analysed using the eBioscience $^{\bullet}$ FlowCytomix $^{\mathrm{mm}}$ Human
Obesity 9plex Kit (Bender MedSystems GmbH, Austria) following the manufacturer's instructions. A standard protein dilution and human plasma samples were incubated with a Bead and Conjugate Mixture for two hours. After washing with assay buffer, a Streptavidin-PE Solution was added and incubated for one hour. Subsequently, samples and standard protein dilutions were washed twice, re-suspended in assay buffer, and analysed by flow cytometry using LSR Fortessa (BD Biosciences, San Diego, USA) with FlowCytomix Pro Software (Bender MedSystems GmbH, Vienna, Austria).

\section{Statistical analysis}

We used GraphPad Prism 6 (GraphPad Software, Inc., La Jolla, USA) for statistical analysis. Pre- and post-TPE levels of all treatments were compared suing the student T-test. This analysis was conducted in the whole study population as well as woman and men separately, the significance level was set at $p<0.05$.

\section{Results}

All enrolled patients completed the two study TPE treatments. The exchanged plasma volume over all treatment sessions was $3570 \pm 589 \mathrm{ml}$, which was $1.1 \pm 0.1$-times the individual calculated plasma volume. The average time period between the first and second therapy session was $25 \pm 5 \mathrm{~h}$.

\section{sICAM-1}

Evaluating all TPE sessions $\left(1^{\text {st }}\right.$ and $\left.2^{\text {nd }}\right)$ plasma levels of sICAM-1 were reduced by $\sim 50 \%$ (from $517 \pm 246$ preTPE to $260 \pm 159 \mathrm{ng} / \mathrm{ml}$ post TPE, $p<0.0001)$. Separate analysis of the $1^{\text {st }}$ TPE session showed a decrease of sICAM-1 from $615 \pm 261$ to $291 \pm 173 \mathrm{ng} / \mathrm{ml}, p<0.0001$. Despite a rebound from $291 \pm 173$ after the $1^{\text {st }}$ TPE to $418 \pm 189 \mathrm{ng} / \mathrm{ml}(p<0.05)$ before the $2^{\text {nd }}$ these levels were still lower than the ones before the $1^{\text {st }}$ treatment (418 $\pm 189 \mathrm{ng} / \mathrm{ml}$ vs. $615 \pm 261, p<0.01)$, suggesting a prolonged reduction effect of TPE on sICAM-1. A total amount of $1.3 \pm 0.9 \mathrm{mg}$ sICAM-1 per treatment was recovered from the total removed collected plasma (Figs. 1a and 2a).

\section{sCD40L}

There was neither a significant decrease in soluble CD40 Ligand plasma levels comparing all pre-TPE and post-TPE levels $(4.4 \pm 2.3$ vs. $3.4 \pm 1.7 \mathrm{ng} / \mathrm{ml}$, n.s.) nor analysing the effect of the $1^{\text {st }}$ TPE alone $(4.8 \pm 2.7$ vs. $3.6 \pm 1.8 \mathrm{ng} / \mathrm{ml}$, n.s.). Furthermore, no significant differences of sCD40L neither in pre TPE plasma levels between the two treatment sessions (pre-TPE 1 vs. pre-TPE 2: $4.8 \pm 2.7$ vs. $3.9 \pm$ $1.7 \mathrm{ng} / \mathrm{ml}$, n.s.) nor from the end of the $1^{\text {st }}$ to the beginning of the $2^{\text {nd }}$ treatment $(3.6 \pm 1.8$ vs. $3.9 \pm 1.7 \mathrm{ng} / \mathrm{ml}$, n.s.) could be detected. We found a total amount of $1.6 \pm$ 
A

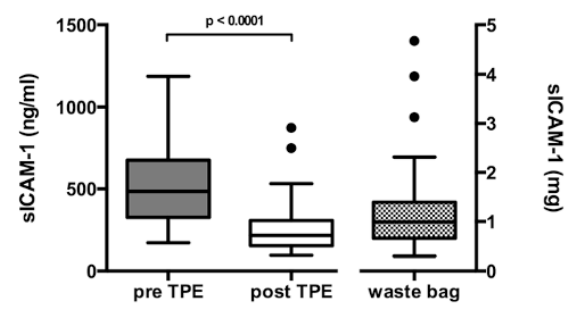

C

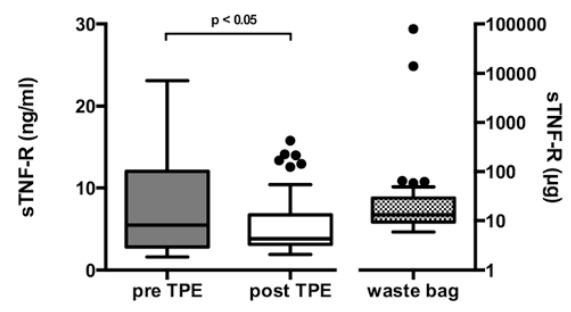

E

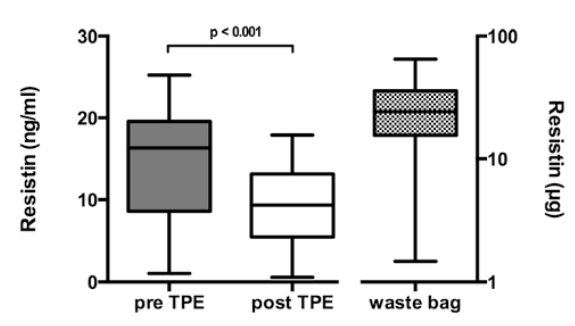

B

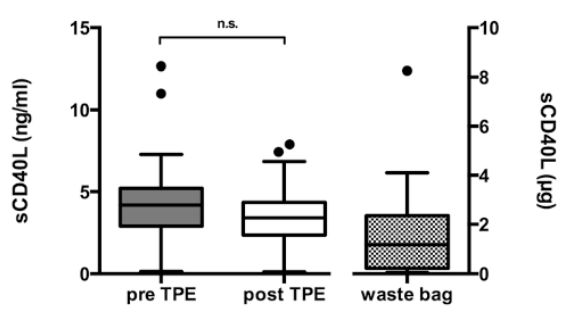

D

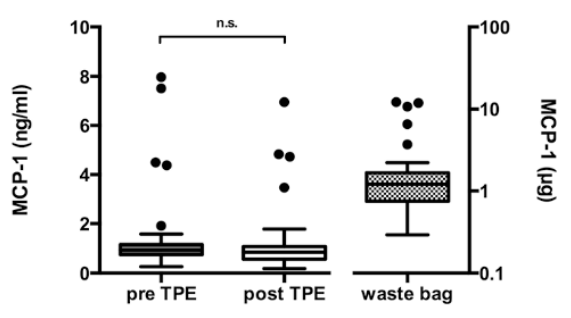

$\mathbf{F}$

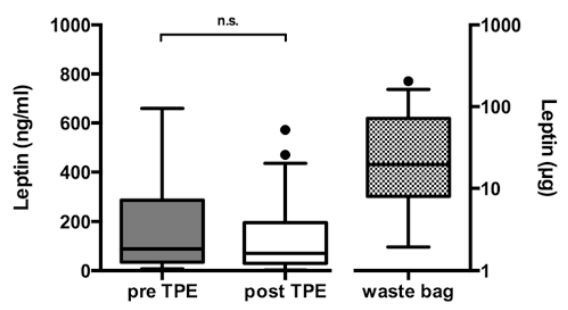

Fig. 1 Pre- and post-TPE plasma levels (left y-axis) of adipokines and cytokines levels summarizing all treatments. Total amount of the respective compounds in the waste bag is shown on the right y-axis. Removal of each investigated molecule is visualized in separated panels (a: sICAM-1, b: sCD40L, c: sTNF-R, d: MCP-1, e: Resistin, f: Leptin)

$1.8 \mu \mathrm{g} \mathrm{sCD} 40 \mathrm{~L}$ in the collected removed plasma. (Figs. 1b and $2 \mathrm{~b})$.

\section{sTNF-R}

There was a significant decrease in soluble TNF-R comparing all pre-TPE to post-TPE plasma levels $(8.1 \pm 6.4$ vs. 5.7 $\pm 3.9 \mathrm{ng} / \mathrm{ml}, p<0.05)$. We found a total amount of $21.3 \pm$ $18.6 \mu \mathrm{g}$ sTNF-R in the collected removed plasma. However, there was no significant decrease in TNF-R plasma levels comparing pre to the post-TPE levels of the $1^{\text {st }}$ TPE treatment alone $(8.3 \pm 6.7$ vs. $5.6 \pm 3.8 \mathrm{ng} / \mathrm{ml}$, n.s.). There was also no significant difference in pre-TPE plasma levels of sTNF-R between the two treatment sessions $(8.3 \pm 6.7$ vs. $7.8 \pm 6.3 \mathrm{ng} / \mathrm{ml}$, n.s.) nor a sTNF-R increase from the end of the $1^{\text {st }}$ to the beginning of the $2^{\text {nd }}$ treatment $(5.6 \pm 3.8 \mathrm{vs}$. $7.8 \pm 6.3 \mathrm{ng} / \mathrm{ml}$, n.s.) (Figs. 1c and 2c).

\section{MCP-1}

There was neither a significant decrease in MCP-1 comparing all pre-TPE to post-TPE plasma levels $(1.4 \pm 1.7$ vs. $1.2 \pm 1.3 \mathrm{ng} / \mathrm{ml}, \mathrm{n} . \mathrm{s}$.) nor looking at the $1^{\text {st }} \mathrm{TPE}$ alone
$(1.5 \pm 1.7$ vs. $1.3 \pm 1.4 \mathrm{ng} / \mathrm{ml}$, n.s.). Despite the lack of effect of TPE on plasma levels we found a total amount of 2.1 $\pm 2.9 \mu \mathrm{g} \mathrm{MCP}-1$ in the exchanged plasma. (Figs. $1 \mathrm{~d}$ and $2 \mathrm{~d}$ ).

\section{Resistin}

Resistin was significantly reduced during TPE comparing all pre- and post-TPE sessions $(14.3 \pm 6.9$ vs. $9.5 \pm$ $4.7 \mathrm{ng} / \mathrm{ml}, p<0.001)$ as well as looking at the first TPE alone $(14.2 \pm 6.9$ vs. $9.4 \pm 4.5 \mathrm{ng} / \mathrm{ml}, p<0.05)$. A total amount of $26.5 \pm 16.3 \mu \mathrm{g}$ resistin was detected in the removed plasma. There was a significant rebound from the end of the $1^{\text {st }}$ to the beginning of the $2^{\text {nd }}$ treatment $(9.4 \pm 4.5$ vs. $14.5 \pm 7.1 \mathrm{ng} / \mathrm{ml}, p<0.01)$. However, the resistin plasma levels prior to the first and second treatment did not differ significantly $(14.2 \pm 6.9$ vs. $14.5 \pm$ $7.1 \mathrm{ng} / \mathrm{ml}$, n.s.) (Figs. 1e and 2e).

\section{Leptin}

There was neither a significant reduction of leptin plasma by TPE comparing all pre-TPE and post-TPE levels (172.8 \pm 169.4 vs. $122.4 \pm 134.2 \mathrm{ng} / \mathrm{ml}$, n.s.) nor analysing the 

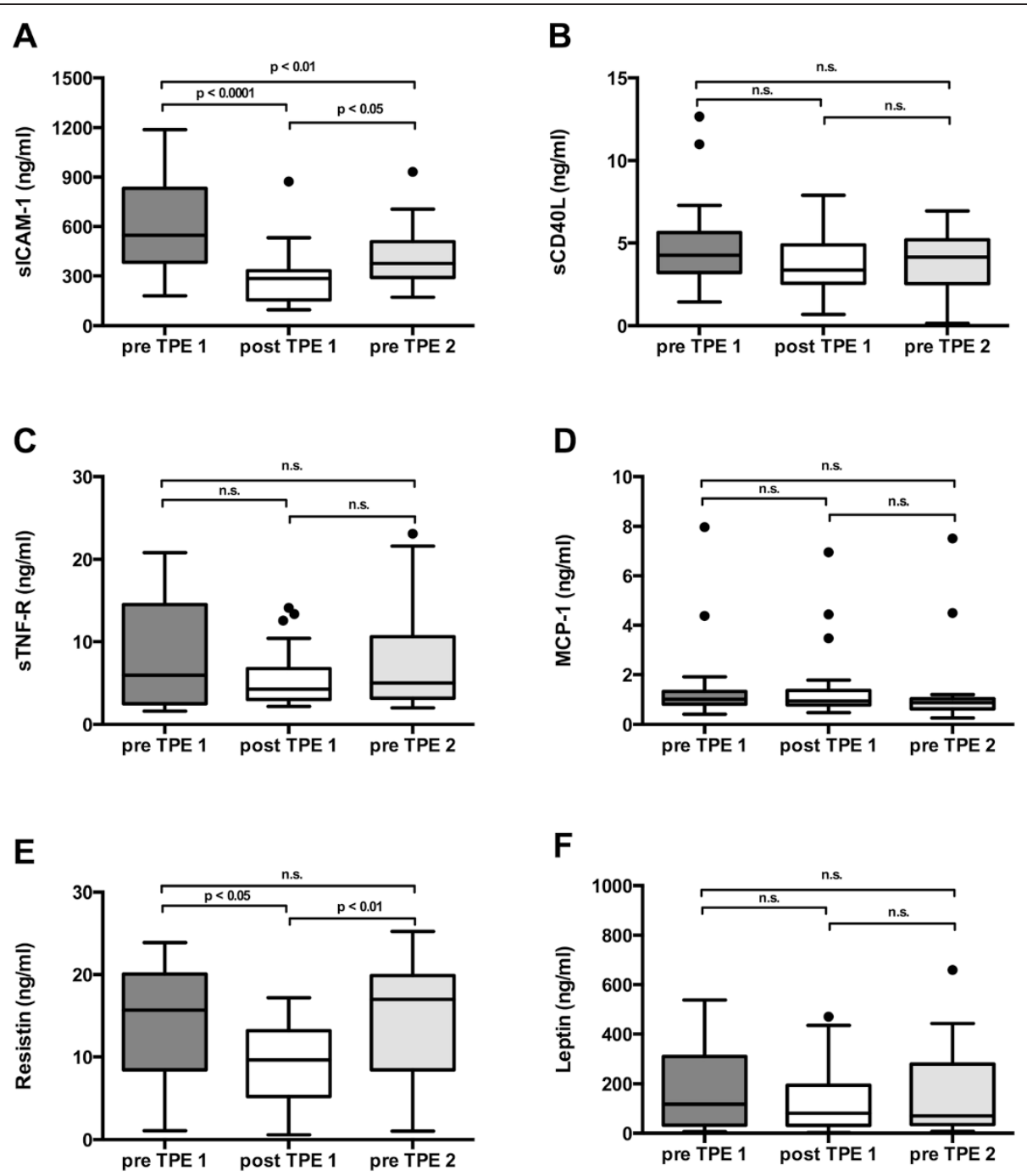

Fig. 2 Time course of adipokine and cytokine plasma levels. Time between end of $1^{\text {st }}$ treatment (post TPE 1) and beginning of $2^{\text {nd }}$ treatment (pre-TPE 2) was $25 \pm 5$ h. Plasma levels of each investigated molecule are visualized in separated panels (a: sICAM-1, b: SCD40L, c: sTNF-R, d: MCP-1, e: Resistin, f: Leptin)

effect of the $1^{\text {st }}$ TPE separately $(178.5 \pm 159.4$ vs. $130.5 \pm$ $135.5 \mathrm{ng} / \mathrm{ml}$, n.s.). We found a total amount of $45.2 \pm$ $49.2 \mu \mathrm{g}$ leptin in the total removed plasma. No significant increase in leptin plasma levels between the end of the $1^{\text {st }}$ treatment and the start of the $2^{\text {nd }} \operatorname{TPE}(130.5 \pm 135.5$ vs. $167.1 \pm 181.8 \mathrm{ng} / \mathrm{ml}$, n.s.). (Figs. 1f and $2 \mathrm{f}$ ).

\section{Gender effects}

Interestingly, in a separate analysis on the effect of gender the female patients revealed a resistin reduction during the $1^{\text {st }}$ TPE treatment (pre-TPE $1_{\text {women }}$ vs. post-TPE $1_{\text {women }}: 17.1 \pm 5.7$ vs. $\left.11.8 \pm 3.8 \mathrm{ng} / \mathrm{ml}, p<0.05\right)$ as well as resistin rebound (post-TPE $1_{\text {women }}$ vs. pre-TPE $2_{\text {women }}$ : $11.8 \pm 3.8$ vs. $17.3 \pm 5.8 \mathrm{ng} / \mathrm{ml}, p<0.05$ ) while men did not. Plasma resistin levels were also significantly higher in women as compared to the male patients before and after TPE (pre-TPE ${ }_{\text {women }}$ vs. pre-TPE ${ }_{\text {men }}: 17.2 \pm 5.6$ vs. $11.2 \pm 6.9 \mathrm{ng} / \mathrm{ml}, p<0.01$; post-TPE ${ }_{\text {women }}$ vs. postTPE $_{\text {men }}: 11.8 \pm 3.9$ vs. $\left.7.1 \pm 4.3 \mathrm{ng} / \mathrm{ml}, p<0.001\right)$.

\section{Discussion}

This study shows for the first time that sICAM-1, sTNF$\mathrm{R}$, and resistin plasma levels are significantly reduced by TPE treatment and quantifies the amount of these substances in the total collected removed plasma. While the effect for sICAM-1 persisted for $25 \pm 5 \mathrm{~h}$, all other investigated markers increased back to baseline in that period of time. These results can also be found in a subgroup analysis, evaluating patients with $\mathrm{BMI}>25 \mathrm{~kg} / \mathrm{m}^{2}$ and with a BMI $<25 \mathrm{~kg} / \mathrm{m}^{2}$ seperatey. There is a gender specific effect of TPE on resistin plasma levels.

There are several aspects to consider in the interpretation of our results. It seems unlike that, the difference in prolonged serum level decrease between the investigated 
substances is due their difference in molecular size. All investigated substances, which range from 12.5 to $89 \mathrm{kDa}$ are clearly below the molecular cut-off of the TPE, i.e.1000 kDa.. Different serum half-life times and different volumes of distribution seem more likely to play a role in the different effects of TPE in the examined markers. This is best epitomized by leptin, which it is not significantly altered by TPE. In the human body it has a very short halflife of 25 min [17]. The half-life of sICAM-1, the molecule which was markedly and prolonged lowered by TPE, is only ill defined as it is highly variable and changes with the underlying disease. However, induced SICAM-1 release in human epithelial cells needs up to $24 \mathrm{~h}$ to achieve a steady state concentration [18], therefore the SICAM-1 serum dynamic is presumably slower than the one of leptin. Adipokine serum levels, except resistin, were generally higher in our patients than in healthy controls described in the literature.

While the effect of TPE on immunoglobulins and immune-complexes [19] or even cardiac markers like troponin and BNP [16] has been shown, data on the effect of other pathophysiologically important mediators are scarce. The most interesting compound in our analysis was sICAM-1. It increases in different inflammatory diseases like vasculitis or psoriasis arthritis [20]. It is believed that the soluble form of ICAM-1 has an active immunologic role due to its interaction with lymphocyte function-associated antigen (LFA-1) [11]. Compared to healthy subjects reported in the literature, the observed plasma concentrations of our patients was markedly elevated. This is in line with previous studies in patients with inflammatory diseases [21]. In ANCA-positive renal vasculitis Tesar et al. proved a significant decrease of sICAM-1 in the TPE treatment period [22]. In our study, we see a marked effect on TPE on SICAM in all patients including those with antibody-mediated rejection after renal transplantation. This might be of clinical importance as sICAM-1 levels significantly correlate with mortality in renal transplant recipients [23]. To our knowledge this is the first time both, a significant decrease of sICAM-1 levels in the patient's blood after TPE and the eliminated whole amount of sICAM-1 in the waste bag, are shown.

Soluble TNF-R is important in inflammatory conditions like spondyloarthritis and is associated with delirium in critically ill patients [24, 25]. sTNF-R levels are increased in our patient group compared with the general population [26]. In the present study we observed a significant decrease in sTNF-R levels of $30 \%$ during TPE treatment. This finding is remarkable, as even extracorporeal liver support systems as MARS ${ }^{\mathrm{mi}}$ (Molecular Adsorbent Recirculating System) or Prometheus ${ }^{\text {Tx }}$ were not able to lower sTNF-R levels [27]. However, the sTNF-R levels did not differ in pre TPE levels between the $1^{\text {st }}$ and the $2^{\text {nd }}$ treatment suggesting a short lived effect on plasma levels, which does not exclude a potential clinical benefit in diseases like spondyloarthritis.

The adipokine leptin could not be lowered by TPE. The role of leptin in inflammatory diseases is controversial. It might be a marker of disease activity in Behçet's syndrome and is elevated in patients with systemic lupus erythematodes [28, 29]. Leptin also seems to decrease in patients with active ANCA associated vasculitis [30]. It is possible that leptin plays an important role in several inflammatory conditions. Yet, we found no significant decrease in leptin plasma levels in our study.

The role of resistin in inflammation is also a matter of debate. While high resistin levels are associated with rheumatoid arthritis, coronary heart disease and insulin resistance, a low resistin plasma level may be correlated with a high hospitalization rate in dialysis patients [31, 32]. Interestingly, the women in our study had higher resistin plasma levels as compared to the male patients. Furthermore, resistin plasma levels decreased significantly in women during TPE. Gender specific differences in resistin levels have been described since the introduction of the molecule [33]. Steppan et al. speculate in a later review that gender differences may be due to differences in body fat distribution or hormone levels [34]. Hormone influence on resistin serum levels seems likely as they are approximately two times higher during premenopause compared to peri- or postmenopause [35]. However, estradiol administration or ovariectomy did not alter resistin serum levels in women [36]. Resistin serum levels seem to be independent from patients' bodyweight and may be a possible risk factor for insulin resistance [37]. In addition, resistin may play a role in breast and endometrial cancer [38]. However, gender specific differences in resistin serum levels are not fully understood and cannot be further clarified by this study, as it was not designed to do so.

Excessive body fat mass in obese patients leads to elevated circulating adipokine levels especially of leptin, resistin, and TNF- $\alpha[39,40]$. We performed a subgroup analysis, where we divided our patients into a group with BMI $<25$ ( 7 women, 3 men) and $>25$ ( 4 women, 7 men). Interestingly, post TPE serum levels for resistin were significantly higher in the lean patient group, while pre TPE serum levels had a similar trend (pre TPE serum levels $\mathrm{BMI}<25$ vs. BMI $>2516 \mathrm{ng} / \mathrm{ml} \pm 1.6$ vs. $11.9 \pm$ $1.3 \mathrm{ng} / \mathrm{ml}, p=0.06$, post TPE serum levels BMI $<25$ vs. BMI $>25: 10.7 \pm 1.1 \mathrm{ng} / \mathrm{ml}$ vs. $7.9 \pm 0.9 \mathrm{ng} / \mathrm{ml}, p<0.05$ ). Therefore, one could postulate, that the gender specific effect on resistin serum concentrations seems to overcome influences of body mass. However, due to the small patient number of this study, subgroup analyses could be misleading. Leptin, one of the central adipocyte-derived hormones, has a major influence on metabolism, immune functions [41], and has often been associated with cell proliferation and cancer development. A reduction of 
these mediators after therapeutic plasma exchange could accomplish positive effects in case of an obesity-related increase of adipokine levels. Furthermore, we demonstrated that altered levels of several adipokines (e.g. resistin and leptin) can decrease the glomerular filtration rate and increase albuminuria [42].

We wish to acknowledge several limitations of our study. Firstly, we only included patients receiving TPE with albumin as replacement fluid as fresh frozen plasma would have interfered with the analysis of the biomarkers. Therefore, our results are valid for patients treated with TPE and albumin as an exchange fluid. Furthermore, underlying illnesses necessitating TPE and other patient characteristics spanned a variety of conditions. Different morbidities may affect the kinetics of the measured marker, as well as differences in the timespan between the treatment sessions. This could lead to an over- or underestimation of the effects of TPE. Additionally, the patient number of our study is rather small and we did not include a follow up period, so clinical relevance of this date cannot be determined.

\section{Conclusion}

In summary, the present study shows a substance- and time-specific removal of various adipokines by TPE. sICAM-1 is the only investigated substance, which shows a prolonged reduction in the patients' serum levels by TPE. Therefore, sICAM-1 plasma levels should be interpreted with caution in patients undergoing TPE. Thus, apart from the removal of autoantibodies and proteins levels of adipocyte tissue derived hormones are altered by TPE. Depending on the specific adipokine, this side-effect of TPE may be (dis)advantageous for the treatment of the underlying disease.

\section{Consent}

All patients gave written informed consent before enrolment into the study. A copy of the written consent is available for review by the Series Editor of this journal.

\section{Abbreviations}

LFA-1: lymphocyte function-associated antigen; MARS ${ }^{\mathrm{m}}$ : Molecular Adsorbent Recirculating System; MCP-1: monocyte chemoattractant protein-1; ICAM1: Intercellular Adhesion Molecule 1; SCD40L: soluble CD40 ligand; sTNFR: soluble TNF-R; TPE: Therapeutic plasma exchange.

\section{Competing interests}

JTK has received research funding from Terumo BCT for an investigatorinitiated study with unrestricted research support, i.e. no influence on the current study. There are no other competing interests.

\section{Authors' contributions}

$\mathrm{CH}$ and JTK treated and enrolled the patients. PG collected the samples. JJS, $\mathrm{JJ}$, JTK and HK evaluated the test results. All of the authors have participated in the discussion and in writing of the submitted manuscript. All authors read and approval the final manuscript.

Authors' information

Not applicable
Availability of data and materials

Not applicable

\section{Acknowledgements}

We would like to thank the nursing staff of our dialysis department for the practical support during the study. The study was supported by institutional funds from the Department of Nephrology and Hypertension of the Hannover Medical School.

\section{Author details}

'Department of Internal Medicine, Division of Nephrology and Hypertension, Medical School Hannover, Carl-Neuberg-Strasse 1, 30625 Hannover, Germany. ${ }^{2}$ Department of Anatomy and Cell Biology, Faculty of Medicine, Martin Luther University Halle-Wittenberg, Halle, Germany.

Received: 30 March 2015 Accepted: 12 September 2015

Published online: 30 September 2015

\section{References}

1. Williams ME, Balogun RA. Principles of separation: indications and therapeutic targets for plasma exchange. Clin J Am Soc Nephrol. 2014;9(1):181-90.

2. Schwartz J, Winters JL, Padmanabhan A, Balogun RA, Delaney M, Linenberger ML, et al. Guidelines on the use of therapeutic apheresis in clinical practice-evidence-based approach from the Writing Committee of the American Society for Apheresis: the sixth special issue. J Clin Apher. 2013;28(3):145-284.

3. De Simone N, Racsa L, Bevan S, Matevosyan K, Valley T, Girod C, et al. Therapeutic plasma exchange in the management of sepsis and multiple organ dysfunction syndrome: a report of three cases. J Clin Apher. 2014;29(2):127-31.

4. Cantaluppi V, Weber V, Lauritano C, Figliolini F, Beltramo S, Biancone L, et al. Protective effect of resin adsorption on septic plasma-induced tubular injury. Crit Care. 2010;14(1):R4.

5. Hadem J, Hafer C, Schneider AS, Wiesner O, Beutel G, Fuehner T, et al. Therapeutic plasma exchange as rescue therapy in severe sepsis and septic shock: retrospective observational single-centre study of 23 patients. BMC Anesthesiol. 2014;14:24.

6. Nakamura K, Fuster JJ, Walsh K. Adipokines: a link between obesity and cardiovascular disease. J Cardiol. 2014;63(4):250-9.

7. Shimomura I, Hammer RE, Ikemoto S, Brown MS, Goldstein JL. Leptin reverses insulin resistance and diabetes mellitus in mice with congenital lipodystrophy. Nature. 1999;401(6748):73-6.

8. Friedman JM, Halaas JL. Leptin and the regulation of body weight in mammals. Nature. 1998:395(6704):763-70.

9. Grunfeld C, Zhao C, Fuller J, Pollack A, Moser A, Friedman J, et al. Endotoxin and cytokines induce expression of leptin, the ob gene product, in hamsters. J Clin Invest. 1996;97(9):2152-7.

10. Long EO. ICAM-1: getting a grip on leukocyte adhesion. J Immunol. 2011;186(9):5021-3.

11. Witkowska AM, Borawska MH. Soluble intercellular adhesion molecule-1 (sICAM-1): an overview. Eur Cytokine Netw. 2004;15(2):91-8.

12. Jayne DR, Gaskin G, Rasmussen N, Abramowicz D, Ferrario F, Guillevin L, et al. Randomized trial of plasma exchange or high-dosage methylprednisolone as adjunctive therapy for severe renal vasculitis. J Am Soc Nephrol. 2007;18(7):2180-8.

13. Poonpet T, Honsawek S. Adipokines: Biomarkers for osteoarthritis? World J Orthop. 2014;5(3):319-27.

14. Aleksandrova K, Jenab M, Bueno-de-Mesquita HB, Fedirko V, Kaaks R, Lukanova A, et al. Biomarker patterns of inflammatory and metabolic pathways are associated with risk of colorectal cancer: results from the European Prospective Investigation into Cancer and Nutrition (EPIC). Eur J Epidemiol. 2014;29(4):261-75.

15. Blake GJ, Ridker PM. Inflammatory bio-markers and cardiovascular risk prediction. J Intern Med. 2002;252(4):283-94.

16. Tutarel O, Golla P, Beutel G, Bauersachs J, David S, Schmidt BM, et al. Therapeutic plasma exchange decreases levels of routinely used cardiac and inflammatory biomarkers. PLoS One. 2012;7(6):e38573.

17. Klein S, Coppack SW, Mohamed-Ali V, Landt M. Adipose tissue leptin production and plasma leptin kinetics in humans. Diabetes. 1996;45(7):984-7. 
18. Wang JH, Devalia JL, Sapsford RJ, Davies RJ. Effect of corticosteroids on release of RANTES and sICAM-1 from cultured human bronchial epithelial cells, induced by TNF-alpha. Eur Respir J. 1997;10(4):834-40.

19. Sanchez AP, Ward DM. Therapeutic apheresis for renal disorders. Semin Dial. 2012;25(2):119-31.

20. Schopf RE, Naumann S, Rehder M, Morsches B. Soluble intercellular adhesion molecule-1 levels in patients with psoriasis. Br J Dermatol. 1993;128(1):34-7.

21. Ponthieux A, Herbeth B, Droesch S, Lambert D, Visvikis S. Age- and sexrelated reference values for serum adhesion molecule concentrations in healthy individuals: intercellular adhesion molecule-1 and E-, P-, and Lselectin. Clin Chem. 2003;49(9):1544-6.

22. Tesar V, Jelinkova E, Masek Z, Jirsa Jr M, Zabka J, Bartůnková J, et al. Influence of plasma exchange on serum levels of cytokines and adhesion molecules in ANCA-positive renal vasculitis. Blood Purif. 1998;16(2):72-80.

23. Connolly GM, Cunningham R, McNamee PT, Young IS, Maxwell AP. Elevated soluble cellular adhesion molecules are associated with increased mortality in a prospective cohort of renal transplant recipients. BMC Nephrol. 2011;12:23.

24. Varkas G, Van Praet L, Cypers H, Elewaut D. Spondyloarthritis and inflammatory bowel disease. Comorbidity and treatment implications. Z Rheumatol. 2013;72(6):524-9.

25. Ritter C, Tomasi CD, Dal-Pizzol F, Pinto BB, Dyson A, de Miranda AS, et al Inflammation biomarkers and delirium in critically ill patients. Crit Care. 2014;18(3):R106.

26. Himmerich H, Fulda S, Linseisen J, Seiler H, Wolfram G, Himmerich S, et al. TNF-alpha, soluble TNF receptor and interleukin-6 plasma levels in the general population. Eur Cytokine Netw. 2006;17(3):196-201.

27. Oettl K, Stadlbauer V, Krisper P, Stauber RE. Effect of extracorporeal liver support by molecular adsorbents recirculating system and Prometheus on redox state of albumin in acute-on-chronic liver failure. Ther Apher Dial. 2009;13(5):431-6.

28. Evereklioglu C, Inaloz HS, Kirtak N, Doganay S, Bülbül M, Ozerol E, et al. Serum leptin concentration is increased in patients with Behcet's syndrome and is correlated with disease activity. Br J Dermatol. 2002;147(2):331-6.

29. Garcia-Gonzalez A, Gonzalez-Lopez L, Valera-Gonzalez IC, Cardona-Muñoz EG, Salazar-Paramo M, González-Ortiz M, et al. Serum leptin levels in women with systemic lupus erythematosus. Rheumatol Int. 2002;22(4):138-41.

30. Kumpers $P$, Horn R, Brabant G, Woywodt A, Schiffer M, Haller H, et al. Serum leptin and ghrelin correlate with disease activity in ANCA-associated vasculitis. Rheumatology (Oxford). 2008;47(4):484-7.

31. Senolt L, Housa D, Vernerova Z, Jirásek T, Svobodová R, Veigl D, et al. Resistin in rheumatoid arthritis synovial tissue, synovial fluid and serum. Ann Rheum Dis. 2007;66(4):458-63.

32. Chmielewski M, Cohen G, Wiecek A, Jesus CJ. The peptidic middle molecules: is molecular weight doing the trick? Semin Nephrol. 2014;34(2):118-34.

33. Steppan CM, Bailey ST, Bhat S, Brown EJ, Banerjee RR, Wright CM, et al. The hormone resistin links obesity to diabetes. Nature. 2001;409(6818):307-12.

34. Steppan CM, Lazar MA. The current biology of resistin. J Intern Med. 2004;255(4):439-47.

35. Sowers MR, Wildman RP, Mancuso P, Eyvazzadeh AD, Karvonen-Gutierrez CA, Rillamas-Sun E, et al. Change in adipocytokines and ghrelin with menopause. Maturitas. 2008;59(2):149-57.

36. Chalvatzas N, Dafopoulos K, Kosmas G, Kallitsaris A, Pournaras S, Messinis IE. Effect of ovarian hormones on serum adiponectin and resistin concentrations. Fertil Steril. 2009;91(4):1189-94.

37. Silha JV, Krsek M, Skrha JV, Sucharda P, Nyomba BL, Murphy LJ. Plasma resistin, adiponectin and leptin levels in lean and obese subjects: correlations with insulin resistance. Eur J Endocrinol. 2003;149(4):331-5.

38. Hlavna M, Kohut L, Lipkova J, Bienertova-Vasku J, Dostalova Z, Chovanec J, et al. Relationship of resistin levels with endometrial cancer risk. Neoplasma. 2011;58(2):124-8.

39. Kalousova M, Sulkova S, Zima T, Deppisch R, Beck W, Bednárová sV, et al. Advanced glycation end products in hemodialyzed patients with diabetes mellitus correlate with leptin and leptin/body fat ratio. Ren Fail. 2003;25(2):277-86.

40. Bluher M. Adipose tissue dysfunction in obesity. Exp Clin Endocrinol Diabetes. 2009;117(6):241-50.
41. Huebner L, Engeli S, Wrann CD, Goudeva L, Laue T, Kielstein H. Human NK cell subset functions are differentially affected by adipokines. PLoS One. 2013;8(9):e75703.

42. Briffa JF, McAinch AJ, Poronnik P, Hryciw DH. Adipokines as a link between obesity and chronic kidney disease. Am J Physiol Renal Physiol. 2013;305(12):F1629-36

\section{Submit your next manuscript to BioMed Central and take full advantage of:}

- Convenient online submission

- Thorough peer review

- No space constraints or color figure charges

- Immediate publication on acceptance

- Inclusion in PubMed, CAS, Scopus and Google Scholar

- Research which is freely available for redistribution 